\title{
LEGAL PROTECTION AGAINST WOMEN VICTIMS OF SEXUAL HARASSMENT THROUGH SOCIAL MEDIA (CYBERPORN)
}

\author{
Sutiani Chorunnisa* \\ Law Tech and Crimes Focal Point, Bogor, Indonesia \\ *Email: sutiani.choirunnisa@gmail.com
}

\begin{abstract}
The need for legal protection for victims of sexual harassment is a must in a state of law as a guarantee of protection and discrimination against women in Indonesia as contained in various international regulations including the Universal Declaration of Human Rights in 1948, then the International Covenant on Civil Rights. and Political Rights 1966, International Covenant on Economic, Social \& Cultural Rights 1966, Convention on the Elimination of all Forms of Discrimination Against Women (CEDAW, Convention on the Elimination of All Forms of Discrimination against Women) in 1979, the Vienna Declaration (1986), the Declaration on the Elimination of Violence Against Women in 1994, and the most monumental is the Beijing Declaration and Platform for Action (1995). The purpose of this study is to analyze the legal protection for women victims of sexual harassment through social media (cyberpron).
\end{abstract}

Keywords: social media; Cyberporn; Sexual Harassment; Women Protection

The Indonesian Journal of International Clinical Legal Education DOI: https://doi.org/10.15294/ijicle.v3i3.48266

Submitted: Dec 12, 2020 Revised: May 23, 2021 Accepted: July 29, 2021 Available online at https://journal.unnes.ac.id/sju/index.php/iccle (C) 2021 Authors. This work is licensed under a Creative Commons AttributionShareAlike 4.0 International License (CC BY-SA 4.0). All writings published in this journal are personal views of the authors and do not represent the views of this journal and the author's affiliated institutions.

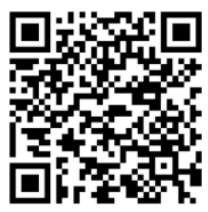


Sutiani Choirunnisa

\section{INTRODUCTION}

Women are creatures of God who must be treated the same as men in all fields, before the law women also have rights equal to men, this is in accordance with Article 28 D paragraph (1) of the 1945 Constitution which reads "everyone has the right to recognition, guarantee of protection, and fair legal certainty and equal legal treatment before the law". In a legal state like Indonesia as according to A.V. Decey always applies three basic principles, namely the supremacy of law, equality before the law, and law enforcement in a way that does not conflict with the law (Due Process of Law). ${ }^{1}$ The same thing according to Friedrich Julius Stahl's concept of the rule of law is characterized by four main elements, namely: ${ }^{2}$

1. Recognition and protection of basic human rights;

2. The state is based on the Trias Politica theory (separation of powers);

3. The government is organized based on the rule of law or legislation (wetmatig bestuur); and

4. The existence of a state administrative court in charge of handling cases of unlawful acts by the government.

Sexual harassment of women is an act that is considered normal and at the same time heartbreaking for women's rights at this time. The existence of legal protection for women so that they are not treated as second-class beings in Indonesia has been carried out with various efforts through the ratification of women's human rights. The existence of the legal umbrella remains the basis for women to equalize with men.

Cyber harassment is a form of harassment that is carried out online such as social media, message boxes, chat rooms or via email with the aim of scaring, intimidating and humiliating victims and perpetrators of cyber harassment generally have the intention of taking revenge. Perpetrators of cyber harassment will often write comments to victims that are meant to do the same. Like the tsunami that blew away all its barriers, the wave of globalization also had the same impact on countries that did not prepare for its arrival. ${ }^{3}$

The development of information technology in Indonesia, one of which is marked by the increasing number of users of interconnected networking services or better known as the internet. ${ }^{4}$ The presence of

1 Munir Fuady. 2009. Teori Negara Hukum Modern. Refika Aditama, Bandung. Pp. 207-208

2 Juhaya S. Praja. 2008. Aliran-aliran Filsafat \& Etika. Prenada Media, Jakarta. p 135

Adi Sulistuyono. 2005. Reformasi Hukum Ekonomi dalam Era Globalisasi. UNS Press, Surakarta. pp. 9-10.

4 Moch. Basarah. 2011. Prosedur Alternatif Penyelesaian Sengketa Arbitrase Traditional dan Modern (Online). Genta Publishing: Bandung. pp. 98-99. See also Chowdhury, Arijit Ghosh, et al. "\# YouToo? detection of personal recollections of 
sophisticated media such as the internet can have a tremendous positive impact on our lives, such as getting and spreading news very quickly. The progress of the internet in addition to having a positive impact also has a negative impact. Computers start to play a role in crime in situations where the capabilities of the computer allow a person to commit that crime or store information related to crime. ${ }^{5}$

Komnas Perempuan stated that there was an increase in the number of sexual harassment against women, especially those carried out through online media. Based on records from Komnas Perempuan, throughout 2019 there was an increase in complaints of cybercrime cases by $300 \%$ or 281 cases from 2018 which was 97 cases. ${ }^{6}$ One example of a case that emerged was online loans that took many female victims, victims were intimidated and forced to pay their debts by sexual harassment such as paying for sexual services, or being asked to send pornographic photos and videos of the victim, even then being distributed to force the victim to pay. Although cases of cyber harassment continue to increase, they are still considered as an iceberg phenomenon, because there are still many things that have not been revealed.

Sexual harassment or sexual harassment is behavior that happens unwittingly anywhere, either in public places such as in transportation facilities, markets, schools, offices or in private places such as home. In the case of sexual harassment, it usually consists of 10 percent of abusive words, 10 percent of intonation that indicates harassment, and 80 percent of non-verbal. Various forms of sexual harassment through online or cyber sexual harassment include messages or comments that are rude, threatening, or indecent, invitations to 'porno action', showing pornographic content, terrorizing sexist languages, and so on that are carried out through internet media, social media, as well as through all kinds of electronic media, computer allow a person to commit that crime or store information related to crime.

Komnas Perempuan stated that there was an increase in the number of sexual harassments against women, especially those carried out

sexual harassment on social media." Proceedings of the 57th Annual Meeting of the Association for Computational Linguistics, 2019; Pendergrast, Tricia R., et al. "Prevalence of personal attacks and sexual harassment of physicians on social media." JAMA internal medicine Vol. 181 No.4, 2021, pp. 550-552; Gunawan, Yordan, Martinus Sardi, and Khairunnisa Khairunnisa. "Perspective of Conven-tion on the Elimination of All Forms of Discrimination Against Women (Cedaw) on the Cyber Harassment in Indonesia." DiH: Jurnal Ilmu Hukum Vol. 16 No.1, 2020, pp. 49-60.

5 Anthony Reyes. 2007. Cyber Crime Investigation Bridging the Gaps, Between Security Professionals, Law Enforcement, and Prosecutors. Syngress Publishing: United States of America. pp. 194-195

6 Komisi Nasional Anti Kekerasan Terhadap Perempuan. 2020. Catatan Tahunan Kekerasan Terhadap Perempuan 2020. Accessed from https://drive.google.com/file/d/18fePLROxYEoNbDuFvH9IEshykn_y9RpT/view 26 June 2020 


\section{Sutiani Choirunnisa}

through online media. Based on records from Komnas Perempuan, throughout 2019 there was an increase in complaints of cybercrime cases by $300 \%$ or 281 cases from 2018 which was 97 cases. One example of a case that emerged was online loans that took many female victims, victims were intimidated and forced to pay their debts by sexual harassment such as paying for sexual services or being asked to send pornographic photos and videos of the victim, even then being distributed to force the victim to pay. Although cases of cyber harassment continue to increase, they are still considered as an iceberg phenomenon, because there are still many things that have not been revealed.

Sexual harassment or sexual harassment is behavior that happens unwittingly anywhere, either in public places such as in transportation facilities, markets, schools, offices or in private places such as home. In the case of sexual harassment, it usually consists of 10 percent of abusive words, 10 percent of intonation that indicates harassment, and 80 percent of non-verbal. Various forms of sexual harassment through online or cyber sexual harassment include messages or comments that are rude, threatening, or indecent, invitations to 'porno action', showing pornographic content, terrorizing sexist languages, and so on that are carried out through internet media, social media, as well as through all kinds of electronic media.

\section{DEFINITION OF SEXUAL HARASSMENT}

Sexual harassment is basically any form of behavior that has a sexual content that is carried out by a person or several people but is not liked and not expected by the target person so that it causes negative consequences, such as: shame, offence, humiliation, anger, loss of selfesteem, loss of holiness, and so on, in the person who is the victim. ${ }^{7}$

Sexual harassment is the most appropriate terminology to understand the meaning of sexual violence. Sexual harassment has a very wide range, ranging from obscene/indecent verbal expressions (comments, jokes and so on) to obscene/indecent behavior (poking, touching, petting, hugging, etc.), showing pornographic/dirty pictures, attacks, and coercion. indecent acts such as, forcing a kiss or hug, threatening to make it difficult for the woman if she refuses to provide sexual services, to rape.

Sexual harassment, because of its wide range, can occur anywhere if there is a mixture of men and women or in a homogeneous community. Sexual harassment is also common in the workplace. Perpetrators of

7 Supardi, S.\& Sadarjoen, "Dampak Psikologis Pelecehan Seksual pada Anak Perempuan", http://www. kompas.com/kesehatan/news/0409/12/201621.htm, 27 June 2020 
sexual harassment are usually men with higher positions or colleagues. This is because in the workplace, there are quite intense relationships between men and women, and the work atmosphere allows the practice of sexual harassment to thrive. However, sexual harassment also often occurs outside the workplace or in public places, and it is even very common to find that the perpetrator is someone the victim does not know, such as sexual harassment on a public bus, on the street, in the market and so on.

Meyer et al. states in general there are three important aspects in defining sexual harassment, namely behavioral aspects (whether it is a sexual proposition), situational aspects (is there a difference where or when the behavior occurs) and legal aspects (under the circumstances in which the behavior is declared illegal). ${ }^{8}$

Based on the behavioral aspect, Farley ${ }^{9}$ defines sexual harassment as unwanted sexual advances by the recipient, where the seduction appears in various forms, both subtle, rough, open, physical, and verbal and unidirectional. Common forms of sexual harassment are verbal and physical harassment, of which verbal abuse is more common than physical. The experts stated that verbal sexual harassment is unwelcome sexual advances, continuous sexual jokes, or messages, asking for a date continuously even though it has been rejected, insulting or degrading messages, suggestive or obscene comments, sexist expressions about body clothing, women's clothing or sexual activity, requests for sexual services expressed by indirect or open threats.

Sexual harassment in the form of physical temptation includes suggestive gazes on body parts (looking at the breasts, hips or other body parts), seductive glances and eye blinking, touching; include pinching, squeezing, tickling, cuddling, and kissing, sexual harassment such as a groping or kissing that occurs due to highly supportive situations such as in elevators, corridors and other quiet spaces after hours, offers of dates in exchange for promotions or cornering women for kisses, sexual propositions, subtle pressures for sexual activity, attempted rape and rape itself.

From a situational perspective, sexual harassment can be committed anywhere and under certain conditions. Women victims of sexual harassment can come from any race, age, characteristics, marital status, social class, education, occupation, place of work, and income. ${ }^{10}$ From an organizational perspective, female trainees experienced the highest percentage of being sexually harassed, but there was no

8 Meyer, M.C., Berchtold, I.M., Oestrich, J., \& Collins, F. 1987. Sexual Harassment. Princeton Petrocelly Book Inc : New York.

9 Farley, L. 1978. Sexual Shakedown: The Sexual Harassment of Women on The Job. New York: McGraw Hill

10 Higgins, L.P., \& Hawkins, J.W. 1993. Wanita dan Pelecehan Seksual. Jawa Pos. 26 April 1992. Bandung 


\section{Sutiani Choirunnisa}

relationship with job category, there was no clear relationship between income level and incidence of sexual harassment, there was a positive relationship between education level and incidents of sexual harassment, there was a positive relationship there is a positive relationship between the level of income and the incidence of sexual harassment, there is a positive relationship between the level of education and the incidence of sexual harassment and there is a very strong correlation between the level of age and dependence on work with the level and frequency of sexual harassment where the younger the more dependent on the job, the frequency of sexual harassment even higher. Women who break into jobs traditionally dominated by men are also more likely to experience sexual harassment than other women. ${ }^{11}$

Tong ${ }^{12}$ mentioned two types of sexual harassment, namely the coercive type of sexual harassment and the non-coercive type of sexual harassment. Coercive sexual harassment includes sexual harassment that offers an advantage or reward to the intended subject, and/or indecent sexual behavior, which threatens to harm the intended subject. Noncoercive type of sexual harassment is sexual behavior that is indecent that only irritates or offends the intended person. The factor that distinguishes the two types of harassment above is the main goal of the harasser, which in the second type is not to make women provide sexual services, but only to irritate or hurt the intended subject.

\section{DEFINITION OF CYBERCRIME}

Cybercrime is a new form or dimension of today's crime that has received wide attention in the international world. Volodymyr Golubev called it the new from anti-social behavior. Several or other cool names are given to this new type of crime in various writings, among others, as cyber space/virtual space offenses, a new dimension of high tech crime, a new dimension of transnational crime, and a new dimension. from white collar crime. Cybercrime, hereinafter abbreviated as $\mathrm{CC}$, is one of the dark sides of technological advances that have a very broad negative impact on all areas of modern life today.

The British Law Commission, for example, defines "computer fraud" as manipulation of a computer in any way carried out in bad faith to obtain money, goods or other benefits or is intended to cause harm to another party. Mandell divides "computer crime" into two activities, namely:

\footnotetext{
11 Tangri, S.S., Burt, M.R., \& Johnson, L.B. 1982. Sexual Harassment at Work: Three Explanatory Model. Journal of Social Issues, 35, pp. 33-54.

12 Tong, R. 1984. Women, Sex and The Law. New Jersey: Rowman and Allanheld.
} 
a) The use of computers to carry out fraudulent, theft or concealment acts intended to obtain financial gain, business advantage, property or services; and

b) Threats to the computer itself, such as theft of hardware or software, sabotage and extortion. ${ }^{13}$

Information technology systems in the form of the internet have been able to shift the paradigm of legal experts towards the definition of computer crime as previously stated, that at first legal experts focused on tools/hardware, namely computers.

However, with the development of information technology in the form of an internet network, the focus of the identification of the definition of cybercrime is further expanded, namely the extent of activities that can be carried out in the cyber/virtual world through the information system used. So it's not just the hardware component that the crime is interpreted as cybercrime, but it can be expanded in the scope of the world explored by the information technology system in question. So it would be more appropriate if the meaning of cybercrime is an information technology crime, as Barda Nawawi Arief said as a Mayantara crime.

Therefore, basically cybercrime includes crimes related to information systems, information systems (information systems) itself, and communication systems which are a means for delivering/ exchanging information to other parties (transmitter/ originator to recipient). ${ }^{14}$

In contrast to conventional crimes, which are characterized by at least a number of things, including the criminals can be anyone (educated common people or educated lay people) and the tools used are simple and the crimes do not need to use a skill. Crimes in the field of information technology can be classified as white color crimes because the perpetrators of cybercrime are people who control the use of the internet and its applications or are experts in their fields. In addition, these acts are often carried out transnationally or across national borders so that two crime criteria are attached at once in this cyber crime, namely white color crime and transnational crime.

Modern here is defined as the sophistication of the crime so that its disclosure is also through sophisticated means ${ }^{15}$. The development of information technology, including the internet, also presents its own challenges for the development of law in Indonesia. Law in Indonesia is required to be able to adapt to the social changes that occur. Social

13 Puslibitang Hukum dan Peradilan Mahkamah Agung RI, Naskah Akademis Kejahatan Internet, (cybercreima), 2004, pp. 4-6.

14 Didik M. Arief Mansur dan Elisataris Ghultom, 2005, cyber LawAspek Hukum Teknologi Informasi, Refika Aditama : Bandung. p. 10.

15 Budi Suhariyanto, 2013, Tindak Pidana Teknologi Informasi (cybercrime) Urgensi Pengaturan dan Celah Hukum, PT RajaGrafindo Persada, Jakarta. p 60 


\section{Sutiani Choirunnisa}

changes 48 and legal changes or vice versa do not always take place together. This means that in certain circumstances the development of law may be left behind by the development of other elements of society and its culture or perhaps the opposite.

Based on some literature and practice, cybercrime has several characteristics, namely: ${ }^{16}$

1) The act that is carried out illegally, without rights or unethically occurs in cyber space/region (cyberspace), so that it is not certain which state jurisdiction applies to it;

2) The act is carried out using any equipment connected to the internet;

3) The act results in material and immaterial losses (time, value, services, money, goods, self-esteem, dignity, confidentiality of information) which tend to be greater than conventional crimes;

4) The perpetrator is a person who controls the use of the internet and its applications; and

5) The act is often carried out transnationally / across national borders.

\section{CRIME OF SEXUAL HARASSMENT ON SOCIAL MEDIA (CYBERPORN) AND THE PROTECTION OF THE VICTIMS}

Etymologically pornography comes from two syllables, namely pornos and grafi. Pornos means an immoral act (in matters related to sexuality), or indecent/obscene acts, while graphics are pictures or writings, which in a broad sense include sculpture objects, the content or meaning of which shows or describes something that is immoral or attack the morals of society.

Briefly, the meaning and scope of the crime of decency can be said that a decency offense is an offense related to (problems) decency. However, it is not easy to determine the boundaries or scope of decency offenses because of the understanding and boundaries according to the views and values prevailing in society, especially because the law itself is essentially a minimum of moral values (das Recht ist das Ethische Minimum).

Juridically, decency offenses according to the current KUHP consist of two groups of criminal acts, namely decency crimes (regulated in Chapter XIV Book II) and decency violations (regulated in Chapter VI Book III). writing or seeing pictures or similar figurines or dolls and tools

16 Abdul Wahid dan M. Labib, 2005, Kejahatan Mayantara (cybercrime), Refika Aditama : Bandung, p. 76. 
to prevent and abort pregnancy, will attack her sense of decency like she feels ashamed or maybe disgusted or also feels guilty. The three pornographic objects are in accordance with the normative law regarding pornography in the Criminal Code. ${ }^{17}$

Law No. 39 of 1999 concerning Human Rights (HAM) in particular Article 45 states that 'Women's human rights are human rights'. Thus, because women's human rights are human rights, these women's rights must be protected, respected, maintained, and should not be ignored, reduced, or taken away by anyone.

It is a fact that acts of violence against women are a constant threat to women everywhere in the world and acts of violence against women have become a global issue. This can be seen from the enactment of a number of international legal instruments as follows:

1. Vienna Declaration and Program of Action (1993);

2. Convention on The Elimination of All Forms of Discrimination Against Women (1979);

3. Declaration on The Elimination of Violence Against Women (1993);

4. Beijing Declaration and Platform for Action (1995). ${ }^{18}$

As a civilized country, Indonesia has ratified the "Convention on the Elimination of All Forms of Discrimination Against Women" with Law no. 7 of 1984, and making a law which is expected to abolish all acts of violence against women in the household, namely Law no. 23 of 2004 concerning the Elimination of Domestic Violence (PKDRT), because it is felt that what is regulated in the Criminal Code is not sufficient to eliminate and even eliminate acts of violence against women.

Of the many opinions about forms of violence against women, the forms of violence against women can be classified into two (2) types of acts of violence against women, namely:

\section{Domestic violence}

Current developments show that acts of physical, psychological, sexual violence and neglect of the household actually occur, so that adequate legal instruments are needed to eliminate acts of domestic violence. In Law No. 23 of 2004 concerning PKDRT in Chapter III starting from Article 5 to Article 9 regulates the "Prohibition of Domestic Violence" and for persons or perpetrators of domestic violence will be subject to criminal sanctions as stipulated in Article 44 to Article 50.

17 Adami Chazawi, 2005. Tindak Pidana Mengenai Kesopanan. Raja Grafindo Persada : Jakarta. pp. 22-23.

18 Harkristuti Harkrisnowo. 2000. Hukum Pidana dan Kekerasan Terhadap Perempuan. Alumni, Bandung. pp. 79-80. 


\section{Sutiani Choirunnisa}

Regarding the forms of violence that can be committed in the household, the main regulation is contained in Article 5 of Law no. 23 of 2004 which stipulates that 'everyone is prohibited from committing domestic violence against people within the scope of his household, by:
a. Physical abuse;
b. Psychological violence;
c. sexual violence; and
d. Domestic neglect.

\section{Sexual violence/harassment}

Sexual violence/harassment is any attack of a sexual nature against women, whether sexual intercourse has occurred or not, and regardless of the relationship between the perpetrator and the victim. Sexual violence/harassment can vary widely in the form of attempted rape, rape, sadism in sexual relations, coercion of other sexual activities that are not liked, demeaning, hurting or injuring the victim.

In the Criminal Code (KUHP) there are several acts that fall into the category of 'sexual violence/harassment', namely:

a. Damaging public decency (Articles 281, 283, 283 bis);

b. Adultery (Article 284);

c. Rape (Article 285);

d. Murder (Article 338);

e. Obscenity (Articles 289, 290, 292, 293 (1), 294, 295 (1))

Furthermore, cyber harassment itself can be categorized as a prohibited act which is contained in Article 27 paragraph (1) of Law Number 11 of 2008 concerning Information and Electronic Transactions which reads: "Every person intentionally and without rights distributes and/or transmits and/or makes accessible Electronic Information and/or Electronic Documents that have content that violates decency"

In addition, offenses related to pornography are regulated in Article 282 of the Criminal Code which contains the following, "Whoever broadcasts, displays or attaches, pictures or objects, whose contents are known and violates morality, or whoever with the intention of broadcasting, showing or affixing them in public, makes such writings, pictures or objects, imports them into the country, or has in stock, or anyone who openly or by circulating a letter without being asked, offers it, or shows it as obtainable. Threatened with a maximum imprisonment of one year and six months or a maximum fine of three thousand rupiahs." 


\section{CONCLUSION}

Sexual harassment through social media where women are victims. This action is motivated by the rapid development of Information and Communication Technology (ICT) which has become much more sophisticated and easily accessible and brings various kinds of benefits, but on the other hand raises various threats of crime, especially against women. Pornography undergoes media translation and can be created with multi-features, if someone is addicted to pornography, it will appear that there is a decrease in social interaction with the environment and it is difficult to concentrate. Pornography is a poison that causes addiction like drugs, the pleasure you get will trigger you to do the same thing until you are bound and difficult to let go. Therefore, it may be necessary to realize that pornography is harmful to health. In addition, cyber-porn is a violation of Articles 281-283 of the Criminal Code (KUHP), prohibiting pornography in any form; and Article 27 paragraph 1 of the ITE Law and Law number 44 of 2008 concerning pornography. In addition to the various arrangements mentioned above, it is necessary to regulate sexual harassment prevention through joint synergy between non-governmental institutions, online media companies and the government itself to combat this issue in the online space. Other regulations in protecting women from the risk of online harassment and sexual abuse in the online realm must be optimized through Supreme Court Regulation No. 3/2017 which contains guidelines for adjudicating women's cases in conflict with the law and the 2007 National Police Chief's Regulation on how to serve female victims in the police.

\section{REFERENCES}

Basarah, M. (2011). Prosedur Alternatif Penyelesaian Sengketa Arbitrase Traditional dan Modern (Online). Yogyakarta: Genta Publishing.

Chazawi, A. (2005). Tindak Pidana Mengenai Kesopanan. Jakarta: Raja Grafindo Persada.

Chowdhury, A. G., Sawhney, R., Shah, R., \& Mahata, D. (2019, July).\# YouToo? detection of personal recollections of sexual harassment on social media. In Proceedings of the 57th Annual Meeting of the Association for Computational Linguistics (pp. 2527-2537).

Farley, L. (1978). Sexual Shakedown: The Sexual Harassment of Women on The Job. New York: McGraw Hill.

Fuady, M. (2009). Teori Negara Hukum Modern. Bandung: Refika Aditama . 


\section{Sutiani Choirunnisa}

Gunawan, Y., Sardi, M., \& Khairunnisa, K. (2020). Perspective of Convention on the Elimination of All Forms of Discrimination Against Women (Cedaw) on the Cyber Harassment in Indonesia. DiH: Jurnal Ilmu Hukum, 16(1), 49-60.

Harkrisnowo, H. (2000). Hukum Pidana dan Kekerasan Terhadap Perempuan. Bandung: Alumni.

Higgins, L. P., \& Hawkins, J. W. (1993). "Wanita dan Pelecehan Seksual". Jawa Pos. 26 April 1992.

Komisi Nasional Anti Kekerasan Terhadap Perempuan. (2020). Catatan Tahunan Kekerasan Terhadap Perempuan 2020. Retrieved from https://drive.google.com/file/d/18fePLROxYEoNbDuFvH9IEshy kn_y9RpT/view 26 June 2020

Mansur, D. M. A., \& Ghultom, E. (2005). Cyber Law Aspek Hukum Teknologi Informasi. Bandung: Refika Aditama.

Meyer, M. C., Berchtold, I. M., Oestrich, J., \& Collins, F. (1987). Sexual Harassment. New York: Princeton Petrocelly Book Inc.

Pendergrast, T. R., Jain, S., Trueger, N. S., Gottlieb, M., Woitowich, N. C., \& Arora, V. M. (2021). Prevalence of personal attacks and sexual harassment of physicians on social media. JAMA internal medicine, 181(4), 550-552.

Praja, J. S. (2008). Aliran-aliran Filsafat \& Etika. Jakarta: Prenada Media.

Puslibitang Hukum dan Peradilan Mahkamah Agung RI. (2004). Naskah Akademis Kejahatan Internet (Cybercrime).

Reyes, A. (2007). Cyber Crime Investigation Bridging Tthe Gaps, Between Security Professionals, Law Enforcement, and Prosecutors. United States of America: Syngress.

Suhariyanto, B. (2013). Tindak Pidana Teknologi Informasi (cybercrime) Urgensi Pengaturan dan Celah Hukum. Jakarta: PT RajaGrafindo Persada.

Sulistuyono, A. (2005). Reformasi Hukum Ekonomi dalam Era Globalisasi. Surakarta: UNS Press.

Supardi, S., \& Sadarjoen, S. (2016). "Dampak Psikologis Pelecehan Seksual pada Anak Perempuan", KOMPAS, retrieved from http://www. kompas.com/kesehatan/news/0409/12/201621.html.

Tangri, S. S., Burt, M. R., \& Johnson, L. B. (1982). Sexual Harassment at Work: Three Explanatory Model. Journal of Social Issues, 35(1), 33-54.

Tong, R. (1984). Women, Sex and The Law. New Jersey: Rowman and Allanheld.

Wahid, A., \& Labib, M. (2005). Kejahatan Mayantara (Cybercrime), Bandung: Refika Aditama. 


\section{"In all societies, both} women and men are powerfully conditioned to repress the daily realities of (sexual harassment and workplace glass ceilings) and to collude with the rest of society in keeping these dimensions of shared experiences hidden."

\section{William Keepin}

Divine Duality: The Power of Reconciliation Between Women and Men 
Sutiani Choirunnisa

\section{Conflicting Interest Statement}

All authors declared that there is no potential conflict of interest on publishing this article.

Funding

None

Publishing Ethical and Originality Statement

All authors declared that this work is original and has never been published in any form and in any media, nor is it under consideration for publication in any journal, and all sources cited in this work refer to the basic standards of scientific citation.

Cite this article as:

Choirunnisa, S. (2021). Legal Protection Against Women Victims of Sexual Harassment Through Social Media (Cyberporn). The Indonesian Journal of International Clinical Legal Education, 3(3), 367-380. https://doi.org/10.15294/ijicle.v3i3.48266 